\title{
PHENOTYPIC AND GENETIC PARAMETERS OF REPRODUCTIVE TRAITS OF BLACK AND WHITE COWS WITH DIFFERENT SHARE OF HF GENES
}

\author{
M.M. Petrović ${ }^{1 *}$, S. Aleksić ${ }^{1}$, T. Smiljaković ${ }^{1}$, V. Pantelić ${ }^{1}$, \\ D. Ostojić-Andrić \\ ${ }^{1}$ Institute for Animal Husbandry, Zemun - Belgrade, Serbia \\ *Corresponding author, e-mail: milan.petrovic@minpolj.sr.gov.yu \\ **Plenary invited paper. Research presented in the paper was financed by the Ministry of \\ Science of Republic of Serbia.Project TR6858 B.
}

\begin{abstract}
In this paper, results of the effect of direct and indirect selection of quantitative fertility traits of cattle end heritability level are presented. Study of the quantitative genetic parameters was carried out on three large farms of Black and White, Holstein-Friesian cattle. Investigation included 3900 first calving cows, daughters of 54 bull sires. The effect of genetic group of the head of cattle (genotype) and of the herd on fertility and milk traits of heifers and first calving cows of Black and White breed was investigated. Genetic group of the head of cattle (genotype) had no significant effect in variation of the fertility traits compared to general average $(\mathrm{P}<0.01)$. The effect of herd caused statistically significant and highly significant deviation from the general average, $\mathrm{P}<0.05$ and $\mathrm{P}<0.01$. Established heritability coefficients for fertility traits had low values for age at insemination $(0,112)$, duration of pregnancy $(0,045)$ and duration of service period $(0,097)$. Results were obtained by applying mathematicalstatistical analysis of data - using mixed model (Harvey, 1990). Mathematical-statistical analysis of data was carried out using linear methods with fixed influence through model of Least Squares (LS method). Genotype of the head of cattle caused no significant deviation of fertility traits $(\mathrm{P}>0,05)$.
\end{abstract}

Key words: reproduction traits, heritability, cow, first calving

\section{Introduction}

If we consider current changes in genetic improvement of cattle and 
great progress in reproduction technologies, it is obvious that programmes which are used today need to be changed and improved, especially because of problems occurring with the disease BSE - bovine spongiform encephlopatia or "mad cow disease". In countries with most developed genetics in cattle breeding, embryo technology is used which enables rapid genetic progress. This is realized through application of new biotechnological methods and procedures aiming to improve the fertility and embryo technology in breeding of cattle of high genetic potential, biotechnological methods in the field of genetics and population genetics, application of new models and methods aiming to improve the conventional quantitative approach - higher accuracy of the estimation of breeding value of heads of cattle, introduction of molecular-biological procedures in genetical analysis of traits of economical importance.

Considering the economical importance of reproductive traits of dairy cattle, the knowledge of certain genetical and para-genetical factors which influence the fertility of cows is necessary. Success in improvement of fertility through genetics is limited by low heritability values, which doesn't mean that genes have no effect on this trait, but rather that value of additive genetic variation is very low. Fertility of cows is under higher influence of environmental factors since variation of reproductive traits is under their influence. Heritability, or study of additive genetic variance in total phenotypic variability of quantitative traits, is part of the major investigations from the aspect of creation of cattle population of high genetic potential and selection of parent pairs for of future generations. Coefficient values for heritability related to fertility traits are under the effect of different factors, such as: genotype of the animal, age, selection intensity, breeding method, conditions of the environment, etc. Heritability coefficients for fertility traits have low hereditary character, but estimated values vary, as stated by Kragelund et al. (1979), Hayes et al. (1992), Petrović et al. (1998). Objective of this research was to investigate major genetic fertility parameters in Black and White cattle in order to choose the direction and further improvement of this population. Similar research was reported by Boie, D. and Gravert, H., (1983), Beaudry et al., (1988), Grigoriev et al., (1987), Petrović et al., (1995, 1997,2006), Vand der Werf and De Boer, W., (1990) and Weller, G. I. and Folman, Y., (1990).

\section{Material and methods}

Investigation of genetic parameters of reproduction traits was carried out 
on sample - representative of the population which included 3900 first calving Black and White cows of different genetic structure - percentage of HF genes (I 50\%HF), (II 75\% HF) and (100\% HF). Investigation included 54 groups of half sisters raised on three large farms near Belgrade. Investigation of phenotypes fertility and heritability included following reproductive traits: - Age at first fertilisation, days (AFFD) - Duration of pregnancy, days (DPD) - Duration of service period, days (DSPD).

In processing of data mixed model of Least Squares with fixed influence (LS - Least Squares) was used, programme LSMLMW, Harvey, 1990. In analysis of the effect of the genetic group of heads of cattle (genotype) and herd on fertility, the following model was used:

$$
\mathrm{Y}_{\mathrm{ijkl}}=\mu+\mathrm{O}_{\mathrm{i}}+\mathrm{G}_{\mathrm{j}}+\mathrm{S}_{\mathrm{k}}+\mathrm{e}_{\mathrm{ijkl},}
$$

where:

$\mathrm{Y}_{\mathrm{ijkl}}$ - individual animal 1, originating from $\mathrm{i}$ bull sire, of $\mathrm{j}$ genetic group and $\mathrm{k}$ herd,

$\mu-$ general population average in equal number of repetitions according to classes - ranks,

$\mathrm{O}_{\mathrm{i}}$ - fixed effect of bull sire (1-54),

$\mathrm{G}_{\mathrm{j}}$ - fixed effect of the genetic group of head of cattle (1-3),

$\mathrm{S}_{\mathrm{k}}$ - fixed effect of the herd (1-3),

$\mathrm{e}_{\mathrm{ijk} \mathrm{k}}-$ other undetermined effects.

\section{Results and discussion}

Different number of individual animals in certain classes, as well as presence of several factors (genotype, herd, bull sires) affecting the demonstration of investigated traits, caused the analysis for which the method of Least Squares was used.

Similar data regarding the age of heifers at first insemination was obtained by Petrović et al. (1995, 1997, 1998). Black and White and Holstein-Friesian heifers can be older at calving which is confirmed by results of Beaudrya et al. (1988) and Nekrasova (1990). Results of our investigation relating to the effect of genotype show that there were no statistically significant differences between groups of genotypes, but certain tendencies were registered. Heads of cattle with the highest percentage of HF genes were inseminated sooner which is in accordance with results stated by Boie and Gravert (1983), Petrović (1994, 1995). 
Table1. Effect of genotype (genetic groups of heads of cattle) and the herd on reproductive traits

\begin{tabular}{|c|c|c|c|}
\hline Traits & AFFD & DPD & DCPD \\
\hline LSM & 493.5 & 276.1 & 107.5 \\
\hline S. E. & 1.7 & 0.1 & 2.3 \\
\hline Genotype & $\hat{\mathrm{c}}_{\mathrm{i}}$ & $\hat{\mathrm{c}}_{\mathrm{i}}$ & $\hat{\mathrm{c}}_{\mathrm{i}}$ \\
\hline I & 2.3 & 0.6 & -3.9 \\
\hline II & 1.8 & 0.1 & 4.7 \\
\hline III & -4.1 & 0.4 & -2.9 \\
\hline F exp. & $0.491^{\mathrm{NS}}$ & $1.400^{\mathrm{NS}}$ & $0.801^{\mathrm{NS}}$ \\
\hline Herd & $\hat{\mathrm{c}}_{\mathrm{i}}$ & $\hat{\mathrm{c}}_{\mathrm{i}}$ & $\hat{\mathrm{c}}_{\mathrm{i}}$ \\
\hline 1 & 0.9 & -0.5 & 4.6 \\
\hline 2 & 10.2 & 0.1 & 1.9 \\
\hline 3 & -8.6 & 0.6 & -2.4 \\
\hline F exp. & $0.4987^{* *}$ & $2.765^{*}$ & $2.318^{*}$ \\
\hline
\end{tabular}

Our research of the effect of genotype on duration of service period showed no significant deviation of this trait. Majority of researchers who performed similar investigations stated similar or slightly longer duration of service period in Holstein cows and Black and White cows with higher percentage of genes of Holstein breed (Grigorev et al., 1987 and Petrovic et al., 1994, 1995). The effect of herd on fertility traits is in accordance with results obtained by Petrović (1987, 1991, 2006) and Petrović et al. (1994, 1995, 2006).Coefficients obtained in study of the additive genetic in total phenotypic variability, i.e. parameters of the heritability of reproductive traits are presented in table 2. Established heritability coefficients for reproductive traits obtained in our research are higher compared to results stated by Moore et al. (1991). Heritability coefficient for duration of service period obtained in this research is similar to those reported by Hayes et al. (1992) and Petrović et al. (1997).

Table 2. Heritability $\left(\mathrm{h}^{2}\right)$ and heritability errors $\left(\mathrm{Sh}^{2}\right)$ of reproductive traits

\begin{tabular}{|l|l|l|}
\hline Trait & $\mathbf{h}^{2}$ & $\mathbf{S h}^{2}$ \\
\hline AFFD (age at fertilisation) & 0,142 & 0,086 \\
\hline DPD ( duration of pregnancy) & 0,093 & 0,057 \\
\hline DSPD (dur.of service period) & 0,101 & 0,091 \\
\hline
\end{tabular}




\title{
Conclusion
}

The effect of the genetic group of heads of cattle (genotype) and herd on fertility and milk traits of heifers and first calving cows of Black and White breed was investigated. Genetic group of heads of cattle (genotype) had no significant effect on variation of fertility traits in relation to the general average $(\mathrm{P}<0.01)$. The effect of herd caused statistically significant and highly significant deviation from general average, $\mathrm{P}<0.05$ and $\mathrm{P}<0.01$. Established heritability coefficients for fertility traits had low values for age at fertilization $(0,112)$, duration of pregnancy $(0,045)$ and duration of service period $(0,097)$. Genotype of the head of cattle caused no significant deviation of fertility traits $(\mathrm{P}>0,05)$.

\section{FENOTIPSKI I GENETSKI PARAMETRI REPRODUKTIVNIH OSOBINA CRNO BELIH KRAVA SA RAZLIČITIM UDELOM HF GENA}

\author{
M.M. Petrović, S. Aleksić, T. Smiljaković, V. Pantelić, D. Ostojić
}

\section{Rezime}

U ovom radu su predstavljeni rezultati uticaja direktne i indirektne selekcije na kvantitativne osobine plodnosti goveda i nivo heritabiliteta. Ispitivanje kvantitativnih genetskih parametara je izvedeno na tri velike farme gde se gaje crno-bela, holštajn-frizijska goveda. Ispitivanje je uključivalo 3900 prvotelki, kćeri 54 bika-očeva. Ispitivan je uticaj genetske grupe grla goveda (genotip) i zapata na osobine plodnosti i mlečnosti junica i prvotelki crno-bele rase. Genetska grupa grla goveda (genotip) nije imala signifikantan uticaj na variranje osobina plodnosti u odnosu na opšti prosek $(\mathrm{P}<0.01)$. Uticaj zapata je izazvao statistički signifikantno i visoko signifikantno odstupanje od opšteg proseka, $(\mathrm{P}<0.05)$ and $(\mathrm{P}<0.01)$. Ustanovljeni koeficijenti heritabiliteta za osobine plodnosti su imali niske vrednosti za osobine uzrast pri prvoj inseminaciji $(0,112)$, trajanje bremenitosti $(0,045)$ i trajanje servis perioda $(0,097)$. Rezultati su dobijeni primenom matematičko-statističke analize podataka - korišćenjem mešovitog modela (Harvey, 1990). Matematičko-statistička analiza podataka je izvršena korišćenjem linearnih metoda sa fiksnim uticajem kroz model 
najmanjih kvadrata (LS metod). Genotip grla goveda nije izazvao signifikantno odstupanje osobina plodnosti $(\mathrm{P}>0,05)$.

\section{References}

BOIE, D., GRAVERT, H. (1983): Kreuzungseffekte bei Kuhen nach der Paarung Holstein-Friesian X Schwarzbunt. Zuchtungskunde, 55 (3), 177185.

BEAUDRY, T.F., CASSELL, B.G., NORMAN, H.D.(1988): Relationships of Lifetime Profit to Sire Evaluations from First, All and later Records. Journal Dairy Science 71 81), 205-213.

GRIGORIEV, J.N., KAZARABIN, D. R., HROMOVA, L. G. (1987): Ispoljzovanije golštinskih bikov v moskovskoj oblasti. Životnovodstvo, 3, 20-24.

HARVEY W.R. (1990): Mixed Model Least Squares and Maximum Likelihood Computer Program. User's Guide for LSMLMW and MIXMDL. HAYES J.F. CUE, R.I., MONARDES H.G. (1992): Estimates of Repetability of Reproductive Measures in Canadian Holstein. Journal of Dairy Science, 75 (6), 1701-1706.

KRAQELUND K., HILLEL J., KALAY D. (1997): Genetic and Phenotypic Relationship Between Reproduction and Milk Production. Journal of Dairy Science, 62 (3), 468-474.

NEKRASOV, D. K. (1990): Visproizvoditeljna funkcija i produktivnost korov $\mathrm{v}$ dvuh pokolenijah $\mathrm{v}$ zavisimosti ot vozrasta pervom otele $\mathrm{i}$ intenzivnosti virašćavania. Izvestia TSHA, 3, 106-119, 1990.

PETROVIĆ M.M., LAZAREVIĆ R., LAZAREVIĆ LJ., ALEKSIĆ S., MIŠČEVIĆ B., NIKITOVIĆ N. (1998): Naslednost i povezanost reproduktivnih osobina $\mathrm{i}$ mlečnosti crno belih goveda. biotehnologija $\mathrm{u}$ stočarstvu 14 (1-2) p. 15-20.

PETROVIĆ M.M., LAZAREVIĆ R., LAZAREVIĆ LJ., MIPČEVIĆ B., ALEKSIĆ S. (1995): Parametri fenotipske povezanosti i zavisnosti reproduktivnih, proizvodnih i osobina dugovečnosti crno belih goveda. Biotehnologija u stočarstvu, 11 (3-6) p. 69-74.

PETROVIĆ M.M., LAZAREVIĆ R., MIŠČEVIĆ B., ALEKSIĆ S., PERIŠIĆ P., DELIĆ N. (1997): Efekat ukrštanja crno belih goveda domaće populacije sa holštajn frizijskom rasom na osobine plodnosti i mlečnosti. Biotehnologija u stočarstvu, 13 (1-2) p. 33-41.

PETROVIC M.M., SMILJAKOVIĆ T., PANTELIĆ V., SRETENOVIĆ LJ., OSTOJIĆ D. (2006): Results of the application of technological-genetical 
procedures in reproduction of cattle with them to improve the milk production. The $35^{\text {th }}$ International Session of Scientific Communications the Scientific papers of the Faculty of Animal Science, Bucharest 2006, Romania, 219-224

VAND DER WERF, J.H.J., DE BOER, W. (1990): Estimation of Genetic Parameters in a Crosbred Population of Black and White Dairy Cattle. Journal Dairy Science, 73 (51), 1318-1326.

TOMEK W., TORNER H., KANITZ W. (2002b) Comparative analysis of protein synthesis, transcription and polyadenilation of mRNA during maturation of bovine oocytes in vitro. Reprod. Domestic. Anim.; 37:86-91.

WELLER, G. I., FOLMAN, Y (1990): Effects of Calf Value and reproductive Management on Optimum Days to First Breeding. Journal Dairy Science, 73 (51), 1318-1326. 